\title{
NIH resolves dispute on cancer gene patent
}

Washington. An acrimonious dispute over who should be named on the patent application covering the breast cancer gene BRCA1 has now been resolved.

Under an agreement announced by the US National Institutes of Health (NIH) last week, two scientists from the National Institute of Environmental Health Sciences (NIEHS) who were omitted from the original patent applications are now listed as coinventors in new applications to the US Patents and Trademarks Office.

The dispute was between the NIH on the one hand and the biotechnology company Myriad Genetics and the University of Utah on the other. The three groups have agreed to work together to develop diagnostic products as rapidly as possible. Meanwhile, the NIH has agreed to withdraw a counterapplication which it filed last November in protest at the original patent filings (see Nature, 372, 118; 1994).

The disagreement erupted last September, in the wake of a paper published in Science announcing the discovery of the BRCA1 tumour suppressor gene. Women who inherit a mutated form of the gene have an increased likelihood of developing breast or ovarian cancer; indeed, a study in the Journal of the American Medical Association puts the lifetime risk for such women of developing breast cancer at 86 per cent.

Shortly before the BRCA1 discovery was made public, the University of Utah and Myriad Genetics filed patent applications

\section{More focus urged for Japan's drug research}

London. Japanese companies need to apply a greater focus to their research and development efforts if they are to compete more effectively with their US and European counterparts, according to an analysis of the global pharmaceutical industry published in London last week by the management consultancy Datamonitor.

An analysis of the relative competitiveness of pharmaceutical companies by region showed that, between 1989 and 1993, the average compound annual growth rate for Japanese companies was only four per cent. This compared to 11 per cent for European companies, and 12 per cent for those in North America.

In Japan, says that report, expenditure on research and development has been lower than elsewhere, with the result that "there is a general lack of new innovative products coming out of most Japanese companies". But the report adds that the picture is now starting to change, with overseas expansion becoming a necessity, and research being targeted more effectively. covering the nucleotide sequence of the gene. The applications named six co-inventors, three from the university and three from Myriad, but not two NIEHS scientists - Roger Wiseman and Andrew Futreal who had worked on part of the gene.

If the patent had been granted in this form, the NIH would not have been entitled to receive any revenue from diagnostic kits or therapies based on the identification of the gene, even though it had both supported the research at NIEHS and contributed to the cost of the work carried out at the University of Utah.

According to Richard Koehn, vice president for research at the University of Utah, the two NIEHS scientists were excluded from the original patent application in order to prevent any third-party challenge on the grounds that the two should not have been named as co-inventors.

Koehn says such an argument could have been made because the two only worked only on parts of the gene, and could not have independently known the full significance of the sequences they were studying. "You can't simply designate someone an inventor", says Koehn, pointing out that the six people named in the original patent applications had access to the whole sequence of the gene.

But an NIH official says that the original exclusion of its scientists could have been a result of a misunderstanding of patent law, pointing out that the scientists inevitably knew what they were working on as a consequence of their collaboration with the Utah groups.

Wiseman's and Futreal's names now appear on those parts of the patent application dealing with the sequence they worked on, and the NIH is entitled to revenue from any commercial product stemming from the patents.

At the same time, the three parties have agreed that exclusive, worldwide commercial rights to the gene are retained by Myriad and its licensees, Eli Lilly and Co. and Hybritech Inc.

Disagreements about who can legitimately be named on a patent are not unusual, according to Kate Murashige, a patent attorney in Washington DC. Only a few months ago, for example, the NIH lost a similar case against the pharmaceutical company Burroughs Wellcome. Last week's announcement of agreement between the NIH, Myriad and the University of Utah should forestall legal action between them.

Helen Gavaghan

\section{Medical schools fight their corner}

Washington. The leaders of more than a hundred US medical schools last week appealed to Congress not to make cuts in two important sources of financing: the reimbursement of costs associated with federally funded research, and a 'medical education' adjustment made on federal payments for care of the elderly.

The academics visited members of both houses - including Newt Gingrich, speaker of the House of Representatives - as part of a massive lobbying effort in support of academic medicine. In particular, they defended the research and teaching that make medical treatment at academic centres more expensive than elsewhere.

At a series of events coordinated by the Association of American Medical Colleges, the visiting medical leaders claimed that social and political changes are combining inadvertently to threaten research and teaching. "You can only take so many hits before the wagon goes in the ditch, and we're about ready," said Jeffrey Houpt, dean of Emory University school of medicine

As observers point out, the problem has been growing for a number of years. Indeed Judith Vaidukaitis, former head of the clinical centre at the National Institutes of Health, and now director of the NIH's National Center for Research Resources, says although the medical centres are "get- ting killed", they "should have seen the truck coming a long time ago".

Several factors contribute to the current problem. One is that the large teaching hospitals treat about half of the indigent patients in the United States - including many individuals who are uninsured, but do not qualify for federally funded Medicaid.

Second, say the medical school heads, the additional costs of teaching and research, combined with the fact that the academic centres treat more complex cases, makes the medicine they practise more expensive than in a non-teaching hospital.

Furthermore, individual states are finding it hard to maintain contributions for indigent patients, while the federal government is contemplating cuts in its programmes for elderly or uninsured patients. And newly formed medical groups offering managed care are demanding reductions in the price of services they contract from the big teaching hospitals.

These factors, say medical centre deans, pose a threat to research and teaching just at a time when modern biomedical research is providing exciting leads for clinical research. "If something is not done now, someone will run for president in $\mathbf{1 0}$ years time on the basis of reinvigorating American medical colleges," says Houpt.

Helen Gavaghan 